\title{
ANTIQUITY
}

present in south-east Europe after its earliest occurrence in Asia Minor, but some thousand years before its previously first-documented appearance in Europe. This discovery would appear to confirm Helbaek's hypothesis (1960) that 'flax reached central and western Europe

BERTSCH, K. and F. BERTSCH. 1949. Geschichte unserer Kulturpflansen (Stuttgart).

BROUWER, W. and A. STAHLIN. 1955. Handbuch der Samenkunde (Frankfurt).

DENNELL, R. W. 1972. The interpretation of plant remains: Bulgaria, in (ed.) E. S. Higgs, Papers in economic prehistory (Cambridge), 149-59.

HELBAEK, H. r 960 . The palaeoethnobotany of the Near East and Europe, in R. J. Braidwood and B. Howe, Prehistoric investigations in Iraqi Kurdistan (Chicago), 99-1 18.

\section{The Cretan 'hornet' pendant}

Professor O. W. Richards, FRS, Emeritus Professor of Zoology and Applied Entomology, Imperial College, London, sends us this interesting note on the Cretan golden pendant commonly described as representing two hornets. This beautiful golden pendant preserved in the museum at Heraklion came from the cemetery of Mallia ( $17^{\text {th }}$ century BC) ( $P L . x x v i b$, left). The postcard commonly obtained in Crete describes the insects as bees which is certainly incorrect. Reynold Higgins, in Minoan and Mycenean art (London, 1967) illustrates the pendant in colour, calls the insects hornets (as do other authors) and dates it from $1700-155^{\circ} \mathrm{BC}$.

To an entomologist, it is clear that the insects represented are not bees and almost certainly not hornets, but very likely a social wasp of the genus Polistes. These wasps have no English name as they do not occur in England though the Germans call them 'Feldwespen'. There are several common species in the Mediterranean which would be indistinguishable to the layman. They can be quite from the Near East via the Balkans and the Danube'. Until the plant husbandry of Mesolithic settlements in Europe is investigated more fully, however, we cannot be certain that flax was not developed as an indigenous rather than an introduced cultivar.

1969. Plant collecting, dry farming and irrigation in prehistoric Deh Luran, in F. Hole, K. V. Flannery and J. A. Neely, Prehistory and human ecology of the Deh Luran plain (Mem. Mus. Anthrop. Univ. Michigan, r: Ann Arbor).

RENFREW, J. M. 1973. Palaeoethnobotany (London). TUTIN, T. G., v. H. HEYWOOD et al. 1968. Flora Europea, vol. 2 (Cambridge).

ZEIST, W. VAN. 1972. Palaeobotanical results of the r 972 season at Çayönü, Turkey, Helinium, XII, I, 3-19.

PLATE xxvib

common in gardens and sometimes build their small combs under the eaves of sheds or houses.

There is a species of hornet in Crete (Vespa orientalis) but the base of the abdomen of the hornet is much more truncate, falling perpendicularly to the point where it is attached to the thorax. The abdomen of Polistes tapers quite gradually to its point of attachment and the pendant gives a very reasonable though somewhat schematized representation of the insect. It is possible that some details of other insects have been incorporated and certain features (e.g. the crenellate wing-margin) have been added purely for decorative effect. The nest of Polistes humilis, an Australian species, illustrated here, gives a somewhat inadequate idea of what $\mathrm{I}$ am talking about, but there is one wasp in profile at the back (marked with a white arrow) that gives some idea of its shape (PL. XXvıb, right).*

* We apologize to Professor Richards for adding to his difficulty in obtaining a good photograph by not being able to print it in colour. $(E d$.).

\section{Archaeology at Lancaster University}

The purpose of this note is to report briefly on the development of archaeological studies at Lancaster University. The University has for some time been keen to establish archaeology as a degree subject and, with recent appointments, degree courses are now planned to begin in 1974-5. The development is taking place in the Department of Classics-now renamed the Department of Classics and Archaeologyunder Professor M. M. Willcock. There are 


\section{NOTES AND NEWS}

four lecturers who will be concerned with the teaching of archaeology: Dr D. C. A. Shotter, a Roman specialist with interests in architecture and numismatics, Mr M. J. Osborne, a Greek specialist with particular interest in epigraphy, Dr T. W. Potter, an Etruscan and Roman archaeologist and $\mathrm{Mr} \mathrm{H}$. M. Blake, a medieval archaeologist with research interests in North Italy. In addition, there is a graduate assistant, Mr D. M. T. Longley, who is concerned primarily with draughtsmanship. Lancaster is also fortunate to have a number of specialists in other departments who will contribute to the archaeological courses, including Dr D. J. Blundell, a geophysicist who has carried out some very successful surveys with the proton magnetometer and resistivity meter on sites in the North-West, and Dr Frank Oldfield, who analysed the pollen samples from the neolithic site of Storrs Moss.

The Lancaster courses, which include both a Part I and Part II, will lead to either a Combined Major or Minor degree in Archaeology. With further staff appointments, it should be possible to offer a Major degree. The scope of the courses will lie primarily in later prehistory, Classical and medieval archaeology, particularly in the Mediterranean, and the main emphasis will be upon a field archaeological rather than art historical approach. Already, this Easter, Lancaster has participated in a rescue excavation mounted by the Italian authorities on a major Etruscan, Roman and medieval site in the Viterbese. However, it is also felt that there should be a strong commitment to fieldwork in North-West England and this academic year rescue operations have been undertaken at three Roman sites, Bowness-onSolway, Burrow-in-Lonsdale and in Lancaster itself. Other projects are planned including a large-scale research excavation of the Roman fort at Watercrook, near Kendal, and a major field survey of the Lune Valley. Laboratories are being set up at Lancaster to deal with the material from this fieldwork, which should do something to extend our knowledge of what is still an imperfectly explored region.

T. W. POTTER

\section{Cropmarks near the Sutton Courtenay Saxon site}

Plate XXVII

During the preparation of a survey of cropmarks in the (new) Oxfordshire Upper Thames Valley (Benson and Miles, 1974), several photographs taken by Professor St Joseph in 1962 attracted particular attention, since they appeared to add new dimensions to the wellknown and much-discussed Saxon settlement at Sutton Courtenay, excavated by E. T. Leeds between 1921 and 1937. (Leeds, 1923, 1927, 1947; Radford, 1957).

The site of these excavations and the area to the south were photographed by Major G. W. Allen in 1933 and 1934, revealing extensive prehistoric features, notably the Drayton Cursus with a terminal to the south-west and a number of ring ditches. These photographs also showed the gravel quarrying which prompted Leeds's work on the Saxon site.

Notwithstanding the clarity of the cropmarks of the cursus, ring ditches and irregular periglacial features on Allen's photographs, no features which could be interpreted as of
Saxon origin were identifiable. Leeds discussed the area of prehistoric features separately from the area of his Saxon site (Leeds, 1934a,b). Re-examination of Allen's photographs provides no apparent trace of Saxon features, but the photographs by St Joseph are much more revealing and two of these are published here (PL. XXVII).

PL. XXVII $a$ taken from the south-west, gives an impression of the setting of the site. The cropmarks (centred SU 486506) lie some $\mathrm{I} \cdot 2 \mathrm{~km}$. south-east of Drayton village and occupy a level portion of the SummertownRadley gravel terrace, at a height of $175^{\prime} \mathrm{OD}$. This terrace falls away to the north and northeast with a distinct scarp down to the wide plain of the Thames. (The river may be seen indistinctly at the very top right edge of PL. Xxvira.) This area, despite the work of the Thames Conservancy, was extensively flooded at the time of a recent visit (February 1974). To the south the level terrace containing the 